\title{
If Walls Could Talk: The Collective Artist-Activist Role In Indonesian Street Art
}

\author{
Abbey Hall, Art History and Visual Arts Department, \\ Faculty of Fine Arts, University of Victoria, \\ British Columbia, Canada \\ abbeyh@uvic.ca
}

(C) 2017 University of Malaya. All rights reserved.

Malaysian Journal of Performing and Visual Arts, Volume 3, 2017

\begin{abstract}
In this article, I argue that the artistic development of Indonesian collectivist street art as an anonymous mode of socio-political activism is vitally important to the building of an awareness of current social issues in Indonesia. In analyzing artist-activist collective Taring Padi's papering of posters and painting of murals in a city in which street art has been co-opted by the government, as well as their utilization of accessible, inexpensive materials and artistic practices to protest political and environmental wrongs, I will demonstrate the collective's ability to provide what I will term an anarchist, non-authoritarian voice in order to educate the broader Indonesian populace. Additionally, with the development of an ever-expanding network of social media and awareness-enhancing events led by the Respecta Art Action Group (RSAG), the people of Indonesia are being given ever more information and outlets for action particularly important in a nation where both have been so desperately needed.
\end{abstract}

Keywords: Street art, artist-activist, database, Indonesia, collectivism

\section{Introduction}

This article revolves around the role of collectivist processes in Indonesian street art and artist-activists in Yogyakarta, while also examining how these artists use their work to revolt against the governing capitalist shackles of their country. I will examine a specific group of Indonesian artist-activists in the post-Suharto era, Taring Padi. Beginning by forming a contextual survey and analyzing their mission statement and collective ways of art making, I exhibit the ways in which this small faction of artists is attempting to rebuild "Cultural Democracy" (Taring Padi, n.d.) and encourage democratic change in Indonesia. Heidi Arbuckle, the leading academic source on Taring Padi, cites the collective as one of the few artistic groups in Indonesia who actively assert that their "cultural praxis is not separate from politics" (Arbuckle, 2006). Having worked with the collective for the past two decades and recently published her doctoral dissertation on the group, Arbuckle provides a unique academic source previously unavailable to researchers. Using Arbuckle's writing, Doreen Lee's work on Indonesian street art, first-hand accounts from art historian Claire Cooper, and content from Taring Padi's official website and social media accounts, I can establish the history and lasting impact of Taring Padi on the Indonesian cultural landscape. 
Furthermore, I will discuss the Respecta Street Art Gallery (RSAG) as part of a new generation of street artists who are also gallery-owners. With the development of an online database in order to connect to a more technologically minded activist population, the RSAG and its supporters are able to distribute images and ideas from a united, egalitarian platform; this results in nationwide events that act as catalysts for social change. In this contemporary era of globalization, as the de-institutionalization of art brings the art of the streets into the wider public scope, street art is becoming the ultimate form of democratization in the art world. It is able to cross both physical and cultural borders to create widespread knowledge of current socio-political issues, even in the wake of capitalization.

\section{Reformasi: The Post-Suharto Regime}

Beginning with a coup on September 30, 1965, General Suharto was established in power after deposing Indonesia's first president, Sukarno. Sukarno's political reform had initially made him the country's most popular revolutionary due to his fervent communist-oriented nationalism and respect for pluralism (O'Rourke, 2002, p. 4). Yet Sukarno's neo-Marxist excesses and the corruption of power resulted in a continuous state of national crisis. Suharto's anti-communist regime began with a bloody, nationwide massacre and the creation of what was termed the New Order. Sukarno's economy had become dramatically unstable and globally mistrusted, and his veiled authoritarianism 1 had finally come to light. Thus, despite the gruesome slaughter of thousands in the name of anti-communism, for years Suharto was heralded as the savior of the country's previously dampened economy, especially by Western capitalist superpowers such as the United States, who had backed Sukarno's overthrow. During Suharto's time in power, Indonesia was routinely hailed by the World Bank as a model developing country; in 1997 Indonesia's economy grew 7.8 percent, slightly more than the annual average since Suharto's rule began in late 1965. Exports reached $\$ 50$ billion in 1996, double the 1991 volume (Schwarz, 1997). Despite initially boosting the nation's economy, the later years of Suharto's presidency revealed the incredible corruption that was being carried out through the upper levels of the government and the military.

\section{Rousing the Creative Youth of Indonesia to Action}

The arts, in particular, felt a dramatic change under Suharto, in contrast to the liberal support Sukarno had given to a pluralistic range of political and cultural ideas. The New Order's

...tacit prerequisite [was] that there was no degree of social commentary of any form: art should be beautiful, either in an abstract way, or -if in a representational style- it must depict pretty, harmonious, and ideal themes and states of affairs. (Wright, The Contemporary Indonesian Artist as Activist, 1993, p. 47)

Creativity, originality, and ultimately society's voices were stifled, resulting in an explosion of rebellion and upheaval. This insurgence was largely led by a small group of artist-activists who took up street art as their weapon, working in a range of artistic 
languages, from the explicit to the allegorical. After being ruled by Suharto's authoritarian regime for over three decades, in 1998 Indonesia embarked on a new phase, called Reformasi. ${ }^{2}$ Tired of corruption and the harsh punishments inflicted on outspoken citizens, artists and students across the country began assembling and protesting Suharto's rule.

Semsar Siahaan, an Indonesian painter and activist, was at the forefront of the antiSuharto movement. As a member of Group '78, he led students in a series of protests demanding Suharto not be re-elected. The student protests of 1978 were more explicitly anti-military, anti-Suharto, and anti-government than those which came before them as the New Order regime became ever more corrupt (Nyman, 2006, p. 67). Siahaan boasted a long history of artistic as well as political activism. In 1981, he protested modern Indonesian art, which he felt implemented the military government's systematic control of art and culture. He was subsequently expelled from the Institute of Technology in West Java. As a result, he was denied a solo exhibition at the Institute in 1983. Siahaan later recalled, "I knew then that I was blacklisted for exhibitions in any education or art institutions in Indonesia" (Green Left Weekly, 2005). From there, he went to the Netherlands and became active with Indonesian expatriate political dissidents, publishing a bulletin in 1983 called For the Sake of Democracy and Human Rights in Indonesia.

In 1988, Siahaan was approved for a solo exhibition at the Jakarta Art Centre. The exhibition became a "rallying cry" (Green Left Weekly, 2005) for Jakarta youth and students in their struggle for human rights and political reforms. In June 1994 Siahaan was involved in organizing an alliance of all Indonesia's NGOs into the Indonesian Pro-Democracy Action, a huge three-day peace demonstration. He has described how, on the final day,

hundreds of military reacted violently to the peaceful demonstrators... I was beaten up by seven soldiers [who] broke my left leg into three pieces. They threw me into the army truck, then threw me to the ground near police headquarters, [with] my left leg spinning around and in hellish pain. Two hours later an army ambulance came and took me - very roughly and by force - to the military hospital. There, they tortured me, bending my broken left leg like a ' $V$ '. They set the leg improperly in a thick plaster cast and put me in isolation for two days, where a military colonel interrogated me. (Owens, 2003, p. 321)

Siahaan's story is only one of many such accounts of governmental violence under Suharto. In the spring of 1998, he and a group of young protesters took a stand against the Indonesian military's record of instigating kidnappings and deaths. On May 8 in Yogyakarta, one of the student demonstrators was killed at Trisakti University. The crisis escalated, and the death toll quickly rose. On May 12 thousands of students gathered at the Trisakti campus for a memorial ceremony, where opposition leaders Megawati Sukarnoputri and Amin Rais addressed the students. Around noon, the crowds outside the campus grew and so did the unrest as riots erupted. Suharto was asked to step down, which he refused, and on May 18 thousands of demonstrating students occupied the grounds, lobby, and roof of the parliament building in Jakarta. Two days later, half a million Indonesians marched in Yogyakarta, and large 
demonstrations were held in various other cities (Beerkens, n.d.). Artists throughout the nation jumped to action, each providing a specific commentary on governmental reactions to the protests. The self-proclaimed "cultural activist" 3 collective Taring Padi created several large murals and woodcut printed posters in opposition. In addition to the use of posters and signs for protest, there were performance art pieces. These included Tita Yogyakarta's Missing and Silent (1998) and Arahmaiani's Show Me Your Heart (1998).

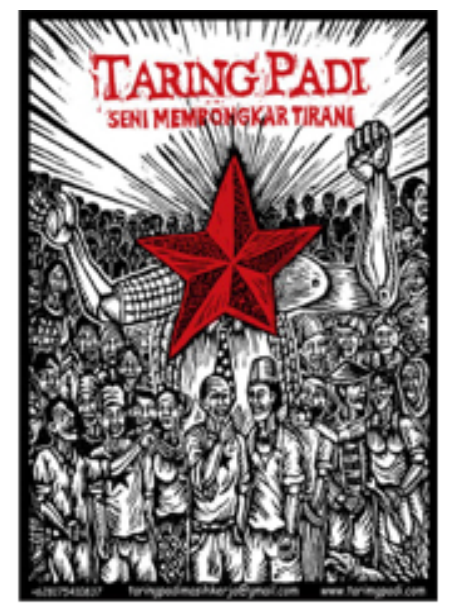

Figure 1. Taring Padi: Seni Membongkar Tirani [Art Smashing Tyranny] by Taring Padi (2012). Reprinted with permission.

The roaring wave of artistic activism from Indonesian youths during this period reflected the contemporary engagement of artists with the rakyat or people, a concept that harkens back to Indonesia's first modern artists. Beginning in the 1930s during the World Depression and guerrilla resistance to the Dutch colonial regime, an art ideology developed that stressed awareness of the rakyat (Bruhn, 2015). The work of artists such as S. Sudjojono, Affandi, and Hendra Gunawan specifically addressed sociopolitical and cultural issues. ${ }^{4}$ Organized collectively around sanggar, or artist workshops, these artists advocated a style that has been described as "socially engaged realism" (Bianpoen, 2009, p. 96). As defined by art historian Astri Wright, activist art is "art with a socio-political message, that aims to further heighten and stimulate awareness about important problematic issues and to increase people's will for active participation in social and political transformation" (Wright, Thoughts from the Crest of a Breaking Wave, p. 49). Artists working on sensitive issues such as labor rights, environmental justice, or the taboo topics denoted by the acronym SARA (ethnicity, religion, race) risked being censored in the New Order years. In her seminal 1994 text on contemporary Indonesian artists, Wright states:

Many of the painters in their late thirties and early forties (artists born in the 1950 s and 60s) refer to themselves as "socially engaged," an engagement, that embraces social, political, and aesthetic dimensions. These artists are protesting against the older generation's definitions of art, aesthetics, and "Indonesian-ness." In their art, they attempt to express reality as they see it rather than according to the idealist and romantic modes of representation they see prevailing in the established Indonesian art world....Their work 
reflects contemporary life in Indonesia, with its commercialism, its urbanrural polarities, and what they experience as increasing social alienation. (Wright, Soul, Spirit and Mountain: Preoccupations of Contemporary Indonesian Painters, 1994, pp. 239-240)

\section{Taring Padi's Collective Cultural Activism}

In keeping with Indonesian artists of the previous generation and their notions of social alienation, engagement with capitalist commercialism, and recognition of the disparity between urban and rural classes, Taring Padi was created as a "cultural organization progressive" (Taring Padi, n.d.) to try to regain social unity between the people of Indonesia and combat wrongs that were being wrought by the corrupt government. Taring Padi consisted of cultural activists, students, cultural workers, and both self- and academically trained painters. Everyone was welcome, the only prerequisite being a commitment to the "populist" mentality (Taring Padi, n.d.). As Toni Volunteero, one of Taring Padi's initial founders, states, there were still many social, political, and economic concerns faced by the Indonesian populace at the time. With a desire to represent those whose voices were rarely heard, Taring Padi set out to create art that would help to educate and give a voice to marginalized communities (Sinaga, 2011, pp. 23-36).

In order to identify "the enemy", so to speak, the collective created what they call Lima Iblis Budaya, or Five Devil Culture. Created in part as a response to Pancasila, the official philosophical foundation of the Indonesian state, the Five Devil Culture manifesto lists the aspects of society that have been shackled for the benefit of capitalism, making arts and culture vulnerable to forces of neo-imperialism and the international market (Taring Padi, n.d.). Pancasila consists of two Old Javanese words (originally from Sanskrit): pañca meaning five, and sīla meaning principles. Pancasila had been co-opted by the New Order, making the matter of interpretation subject to state legislature while being separated from any single group or person. Pancasila began to have legal implications with the government's statement that "Pancasila became the basis of all effective laws" (Song, 2008, p. 157). By granting it legal force, Pancasila was integrated into the realm of the legal sphere, giving the New Order ultimate authoritarian power.

In order to create an understanding of "democratization", Taring Padi creates art that depicts its ideological principles, to try to create a mutual respect between artists and society that reflects the cultural heritage of Indonesia.

\section{Five Devil Culture, from the Institute of Popular Culture (1999)}

1. Institutions of culture emphasize art for art's sake. They are composed of individual opportunists who lead socialized doctrines astray with the aim of maintaining the status quo and who seek to keep the development of art in society, and for whom society is divided into hierarchical classes of economic ability.

2. Governments/authorities (through the ministries in charge of arts and culture) do things that support the status quo. They seek to establish Indonesian culture 
in order for it to be sold in the guise of exoticism for economic interests and power.

3. Art institutions help the government to legitimize the control of artists and artwork, which determines the direction of the development of art.

4. This system damages artists' morale because it only fights for individual interests without thinking about the interests of the people. It even exploits the sufferings of the people for the benefit of the individual.

5. There is a lack of understanding of the function of art in society as a result of New Order politics that emphasized "Economics as Commander", Collusion, Corruption, and Nepotism as a tack.

From reading this manifesto, it seems clear that Taring Padi holds strong socialanarchist beliefs, stemming from a deep mistrust of the government and support of a non-hierarchical network of communication, coordination, and mutual support amongst autonomous nodes of social struggle. The anarchist principles of direct action and mutual aid are especially important, as the collective provides support for social movements' struggles, advocates forms of resistance which maximize respect for life and oppressed peoples' rights, and helps with the construction of local alternatives to global capitalism.5 Although members prefer to designate themselves as "free" (MacPhee, 2007, p. 122) rather than ascribing to a definitive anarchist or communist label, a 2006 interview quotes Volunteero as stating:

Some people continue to study communist authors, but I think generally we are more anarchist. We had people who were very close to the Young Communist party, and we are still close to them, but not like before. ...But we can still sit down in Taring Padi, the communists and the anarchists. We don't spend much time finding out ideologically where people come from, the farmers and other people that we work with. If they're independent and want to talk about problems, subjects of interest to us, then okay, we can get together. (MacPhee, 2007, p. 123)

In response to what Taring Padi refers to as the Indonesian government's attempt to "establish Indonesian culture in order for it to be sold in the guise of exoticism for economic interests and power," cultural democracy would guarantee that many cultural traditions could co-exist in human society, and that none of these would be allowed to dominate and become an "official culture". In the same 2006 interview, Volunteero describes a change in formation enacted in 2003:

Inside the collective mind of Taring Padi, a lot of people started to get a hold of a more libertarian ideology - anarchism, individualism, something like that. ...We're no longer centralized. You can connect directly with anyone to find out about the group. (MacPhee, 2007, p. 123)

Arbuckle describes the collective's methodology as following a local practice of nongkrong (hanging out) and ngobrol (chatting). She states that Taring Padi uses nongkrong as "an informal way to develop ideas. When an idea flourishes, it is subsequently fleshed out at the level of ngerembug (discussion) involving group 
process and participation" (Arbuckle, 2006). A large component of the idea of cultural democracy is participation, which also harkens to the kind of decentralized community ethic of gotong royong. Gotong royong is an Indonesian cultural tradition that entails working together, similar to the anarchist notion of mutual aid.

According to Goldbard and Adams, cultural democracy proposes a life in which everyone is free to participate. This means the right to free expression must be protected; censorship and restriction of freedom are obviously not compatible with a dynamic cultural life. People must have access to the means of expression: paper and pens and stages and musical instruments, as well as help in learning to use them (Cultural Policy and Cultural Democracy, 1990, pp. 107-109). Taring Padi's cultural democracy does not conform to the Western ideology of "a system of government by the whole population or all the eligible members of a state, typically through elected representatives" (Oxford Living Dictionaries, n.d.). Instead, the key idea of practicing social equality far outshines the idea of elected representatives speaking for the majority of the population. The collective strives to provide a voice for the minority: for those who have been silenced and ignored by what is supposed to be a democratic system of governance.

\section{Creativity and the Collectivist Process put into Practice}

Dolorosa Sinaga describes the emergence of Taring Padi in December 1998, stating how

Through art, they began building an understanding amongst the people to fight against injustice, helping to forge a community aware of environmental, social, political and cultural issues, inviting the community to be active and courageous in voicing their real-life experiences and their opinions on the performance of government. (Sinaga, 2011, p. 28)

With a desire to continue the fight of the student movement, the founders of Taring Padi set out to advocate tactics of a united front in order to encourage democratic change in Indonesia. They also use collectivism as a way to counter the bourgeois notions of the "genius artist" and "work of art" as a unique object made by a single artist to be viewed in a highly controlled, often elitist space.

Taring Padi rejects the personal claim on the creation of art, positioning itself as responsible for setting an example for a democratized society. Due to its vehement disassociation from the Indonesian government, the collective is completely selffunded. In an interview for the Sydney Morning Herald, Sunanda Creagh asked print artist Fitriani if Taring Padi ever received funding. Her interviewee seemed shocked by the question, responding: "That doesn't ever happen. We are always opposing the Government. We don't believe in art for art's sake. We make art that's not always just about beauty but is also educational and political" (Creagh, 2006). This art, which predominantly features woodblock prints, murals, and wayang (large Indonesian shadow puppets), is incredibly cheap to make due to the materials used. The artwork is kept in the realm of "low art" 6 due to the inexpensive materials and communal moniker, furthering Taring Padi's desire to not privilege individual artists. Claire Cooper, an instructor in the Department of Media Music Communication and Cultural Studies department at Macquarie University in Australia, writes of the intensely artistic 
experience of collective production in both Australia and Indonesia. Inspired by the 2014 political woodblock posters seen as part of the Indonesian Australian Design Futures Project, she went to Yogyakarta to experience Taring Padi's collectivism firsthand. Cooper states:

Collective improvisation as a creative practice is intensely social, trusting, unpopular, anti-hierarchical and, for these reasons, political. We improvise to be present. To embrace risk and failure over pre-determined results. When we perform our collective improvisations with no prior planning or risk management strategy or foreseeable (profitable) outcome, we are publicly stating that we trust one another. From experience, we've found that this trust, our combined risk and a recognition of shared, unique moments are worth the potential public faltering, humiliations and failures. (Cooper, 2016)

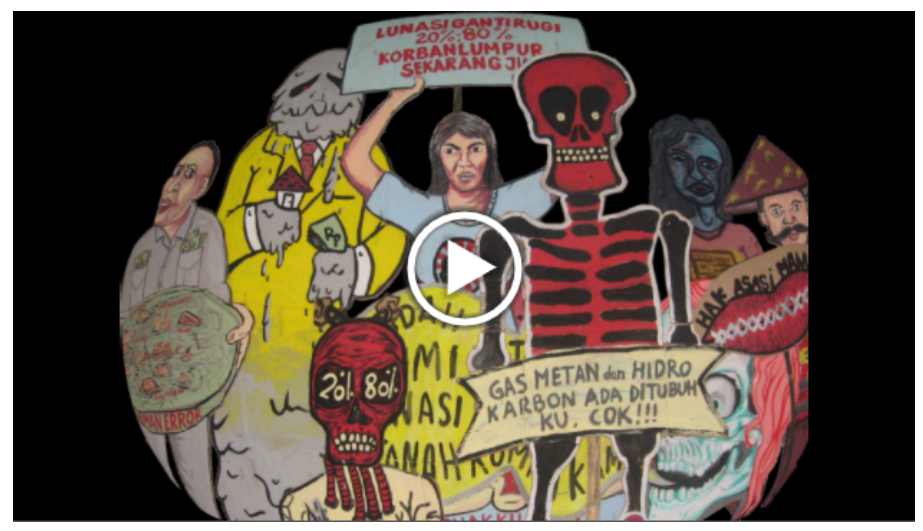

Figure 2. Film still of Reflecting in the Mud (Taring Padi, 2012). Licensed under Creative Commons on Engagemedia.org

Cooper's article provides great insight into the collective process of Taring Padi. In the group's Yogyakarta studio, she observed many members of the collective "...waiting with poised brushes around the edges of a huge, blank canvas, waiting for someone to begin the story told by their collective image. Someone would begin and, like an explosion, the action would spread across the canvas" (Cooper, 2016). Here, as in the multiple videos found on such social media outlets as YouTube and Facebook, the intense and incredibly exciting communal energy that goes into Taring Padi's projects is palpable. To encounter such vibrant cultural-political activity in one's own environment undoubtedly incurs a strong reaction, by both citizens and law enforcement. Taring Padi hopes the viewing of its posters will educate citizens about the wrongs being committed by the government and provide an avenue of action for those who feel as if one voice alone is not enough.

I will now use Taring Padi's commemorative project, Reflection in the Mud, in Sidoarjo, East Java, as a case study to describe one type of art object that results from the collective process, while also showing the ways in which each object is put to use. Reflection in the Mud was a march held in reaction to the Lapindo mudflow disaster, which began on May 29, 2006 and, at its peak, spewed mud at rates as high as 160,000 cubic meters per day. The disaster was caused by the blowout of a natural gas well drilled by PT Lapindo Brantas, an Indonesian oil and gas exploration company. The hot 
mud flooded the rice fields, residential, and industrial areas. Thousands of houses were damaged, tens of thousands of villagers were displaced, and agricultural areas, plantations, and factories were destroyed with devastating environmental consequences. The event became a catalyst for social fragmentation due to the combined loss of history, life, capital, and social interaction (White, 2012).

Engaging with Astri Wright's definition of socially engaged art, quoted above, Claire Bishop describes the political-creative act as a response to contemporary capitalism. Bishop argues that, in order to "re-humanize a society rendered numb and fragmented by the repressive instrumentality of capitalist production", socially engaged artists assign value to what is made invisible in the process of an art object's production, namely a group dynamic, a social situation, a change of energy, or a raised consciousness (Bishop, 2012, p. 35). Working with the residents of Sidoarjo and the University of Michigan, Taring Padi facilitated several workshops to teach community members the techniques of woodblock- and screen-printing. The cultural and artistic activities hosted were focused on reviving the collective memory of the victims. They addressed the events of culture, relationships, and social interaction that were left under the mud. Taring Padi hoped that the rise of collective memory would reinforce the cultural ties, breaking the tension that had been prominent among the victims (White, 2012).

Citizens of all demographics joined in these workshops, creating posters and T-shirts with messages that read, Gasmu meracuni tubuh kami (Your gas is poisoning our bodies), Kembalikan tempat bermain kami (Give us back our place to play), and Kami menolak jadi korban (We refuse to be victims) (Bruhn, 2015). The hand-painted banner held at the front of the march reiterated the outrage and victimization the residents of Sidoarjo felt, stating, Tuntaskan Gantirugi Korban (Demanding restitution for the victims). These posters, banners, and t-shirts were predominantly created using woodblock printing techniques. Once the block had been carved, the citizens of Sidoarjo could assist with rolling on the ink, laying the block onto whatever medium was being printed upon, and then take turns physically stepping on the overlaid newspaper, in order to push the wet ink into the wood, fabric, or other materials. Old or young, male or female, wealthy or poor, each person contributed to the making of the artwork in a demonstration of collective creativity. The posters and banners, along with wayang puppets and masks created by workshop participants, were used in a parade held on the last day of the collaborative event.

\section{Leaving a Lasting Legacy: Murals, the Law, and Public Consciousness}

Reflections in the Mud is only one of several recent examples of Taring Padi's amalgamation of art and politics, community and creativity. ${ }^{7}$ Although the remaining banners and wayang would have most likely been put into storage or thrown away after the event, the resulting t-shirts, posters, and murals leave a lasting legacy. This very visual, very public legacy is what makes the application of murals, posters, and street art in general such an important part of the cultural democracy Taring Padi advocates. 


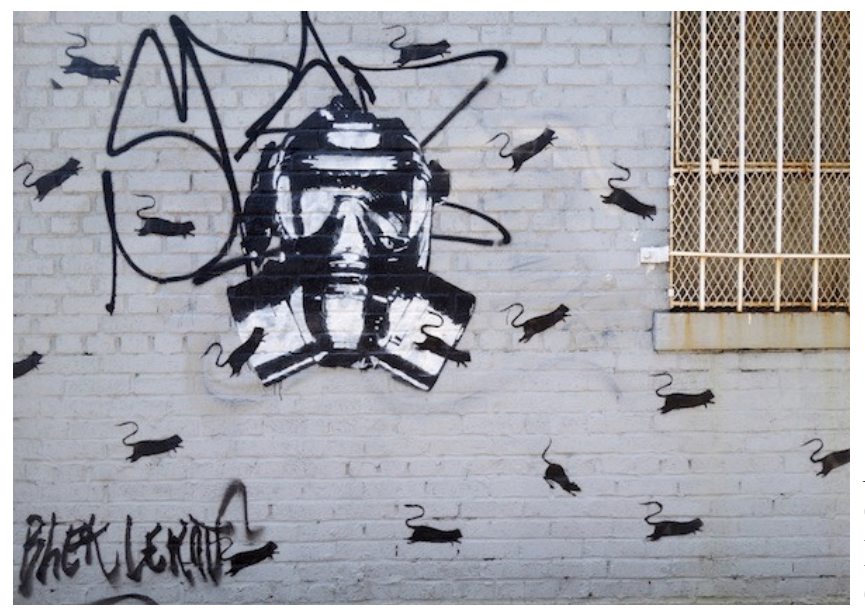

Figure 3. Brooklyn street art by Currystrumpet (2013). Licensed under Creative Commons on Flickr.com

Since the 1990s, street art has gained a lasting presence in the art world and the broader cultural sphere. It has even become a common topic in contemporary Cultural Studies, largely because of its socio-political function (Sanches \& Silva, 2016, p. 6). Cultural geographer L. Dickens calls modern street art "post-graffiti" and argues that tagging "as the core component of graffiti writing, is increasingly being replaced by "street logos'; a shift from typographic to iconographic forms of inscription" (Dickens, 2008). After interviewing street artists, ethnographer R. Schacter has concluded that they ultimately seek "alternative ways of approaching public space" to make "meaningful connection to their surroundings" in pursuit of artistic expression that aims to "reaffirm the city as a place of social discussion" (Schacter, 2008, pp. 36-61). Although not all street art or graffiti contains an overtly political statement, until very recently, producing such art has been an illegal action worldwide. 8 This made it the perfect medium for anti-establishment or anti-authoritarian views, especially as it provided a predominantly anonymous authorship. "Tags" or the artist's unique signature, and "throw-ups", simple stylized letters that usually contain one or two colors, are starting points for any street artist. They were developed as quick ways for artists to leave their marks while evading authorities. The widespread proliferation or "bombing" of these tags and throw-ups is generally considered an unwelcome destruction of public or private property.

A 2014 article by Madeleynn Green cites a Cornell University study designed to determine the socio-political motivations and implications of urban graffiti's most recent incarnation, street art. The study began by documenting hip-hop graffiti's dissemination from the East Coast of the United States to Europe. French street artist Blek le Rat began spray painting stencil images of small rats and army tanks on Paris streets in the early 1980s, after visiting New York in 1971 and witnessing the large amount of graffiti in that city. Blek began by spraying New York-style graffiti in France but soon turned to using stencils, popularizing this style in Europe. As one of the "first"9 street artists, Blek's artistic skill and emphasis on aesthetics aided in the succinct articulation of socio-political grievances. A turn away from the traditional, text-based roots of stencil graffiti, which has in its origins the protest stencils utilized by Latin American student groups in the 1960s and Italian fascist propaganda during 
the Second World War, Blek's street art focused less exclusively on critical typography. Instead, it was primarily based on seemingly arbitrary images.

Blek's iconic images of rats and tanks influenced other European street artists and drew a new distinction between graffiti and street art. This popularized a postmodern function for graffiti: to interact with and enhance the built environment (Green, 2014). Today, Blek's influence is immediately recognizable in the work of the internationally renowned, yet anonymous, street artist Banksy. Along with a few other notable street artists, 10 the British Banksy has become a symbol of the commodification of the street art world, with prices for his appropriated pieces soaring into the hundreds of thousands of dollars. Banksy's identity has remained unknown, creating a previously unbeknownst fervor in collectors and the general public alike. A new installation or stenciled wall could be seized by anyone who happened upon it, a "golden ticket" for a random passer-by, with none of the proceeds going to Banksy himself.11

Street art has also been co-opted by governments all over the world, following a surge of graffiti tourism in such cities as Sao Paolo, Brazil. In Sao Paolo, the term grafite (graffiti) is used to distinguish its practice from one of pixação (tagging). Graffiti works are linked to "artistic" and "political" purposes and are recognized by their visual-aesthetic powers and the positive impact they can have on the landscape (Sanches \& Silva, 2016, p. 7). To quote Andrea Brighenti,

graffiti writing is a field whose definition is problematic for a number of reasons... it is difficult to identify its boundaries. Writing interacts and often overlaps and interweaves with the fields of other practices...including art and design (as aesthetic work), criminal law (as vandalism crime), politics (as a message of resistance and liberation), and market (as merchandisable product). (Brighenti, 2010, p. 316)

Southeast Asian governments have caught on to the trend of marketable graffiti, with street art tourism on the rise in cities such as: George Town, Malaysia; Phnom Penh, Cambodia; Singapore; and, of course, Yogyakarta, Indonesia.

\section{Southeast Asian Street Art as Marketable for Tourist Dollars}

Although global street art has been traced by Western scholars back to student protest groups in France and Germany and Italian Fascist propaganda in the 1950s and $1960 \mathrm{~s}, 12$ there is evidence of political murals having been painted in Indonesia as early as 1946. A mural in Tangerang on a concrete bunker still exists today. While there has been, until recently, little official documentation of this ephemeral art form, artists involved in Singapore's early street art scene estimate that their community started in the 1990s, with the formation of street artist collectives known as crews. "Singapore was one of the first street art scenes to start in Southeast Asia, and had some influence on early scenes in neighboring countries like Malaysia, the Philippines and Indonesia," says Zul Othman, founder of Singapore street art crew RSCLS. Zul, who also goes by the moniker ZERO, is the first street artist in Singapore to be awarded the National Arts Council (NAC)'s Young Artist Award in 2013 for artistic excellence and his role in paving the way for the Singapore street art scene (Seah, 2014). Endorsement by the authorities has helped shift the perception of street art away from petty vandalism to recognizing it as an art form in its own right. "Street art gives our city an exciting edge 
and energy, and the NAC believes that it plays an important role in shaping Singapore's cultural identity," says Aruna Johnson, deputy director of Youth Arts, NAC. "In recent years, we have seen an increased acceptance of and growing interest in this art form, especially among youth in Singapore, and we want to encourage its development" (Seah, 2014).

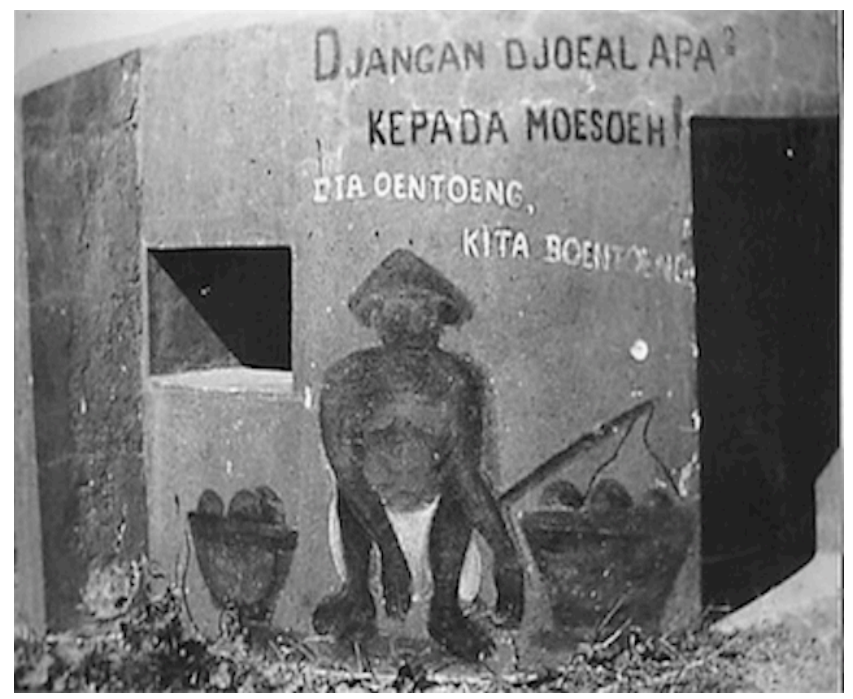

Figure 4. Mural in Tangerang on Concrete Bunker Wall (Unknown, 1946). Licensed under Creative Commons from The National Archives of The Netherlands Database.

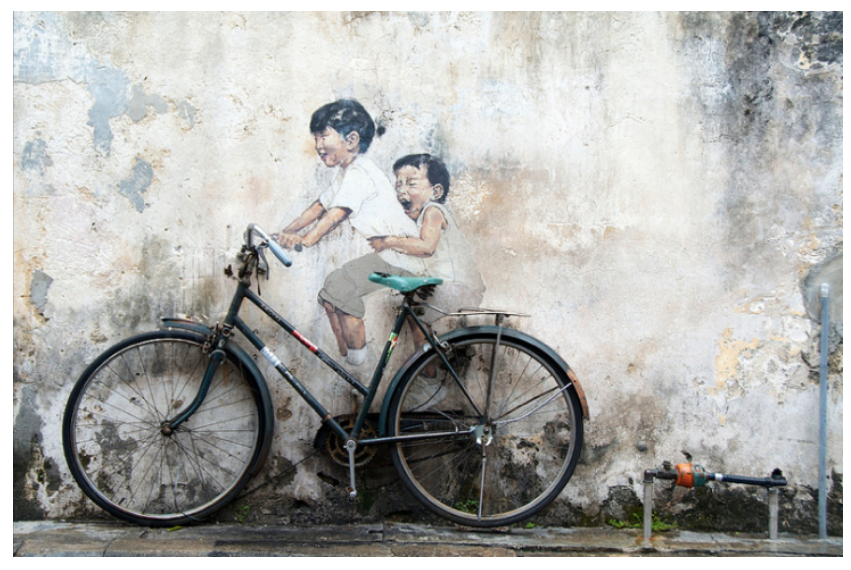

Figure 5. Bicycle Mural by Ernest Zacharevic (Girardet, 2013). Licensed under Creative Commons on Flickr.com

Although there is still a fine associated with illegal tagging, 13 more and more funding and "open space" is being provided as Southeast Asia capitalizes on this rising trend. In 2012, 27-year-old Lithuanian Ernest Zacharevic produced a series of six murals, all of them commissioned by Mirrors. This art project was part of the 2012 George Town Festival, which celebrates Penang's World Heritage induction every August. As locals and tourists swarmed to the locations of the paintings, images posted on social media soon went viral. Zacharevic's bicycle mural went on to be selected by the Guardian as one of the world's best pieces of street art of 2013 (Ferrarese, 2014). "It all started when we decided that the city needed a new life injection," says Chin Poh Chin, president of the Penang Tourist Guides Association. He continues: 
George Town and Melaka were recognised by Unesco in 2008, but before the street art trend, it was rare to see young people gather in the heritage zone after dusk. The art transformed George Town from a ghost town into a trendy place to be. We don't mind using the murals as a promotional façade, so long as it helps people see the real living heritage of George Town. (Ferrarese, 2014)

Yogyakarta has also wholeheartedly embraced street art as government-sanctioned propaganda. In taking cues from the rest of the world's government and tourism departments, Yogyakarta authorities have rebranded the city as a "city of murals".

According to academic and Indonesian street art expert, Doreen Lee, by 2008 more than 500 murals had been created in Yogyakarta, predominantly addressing social issues such as health, hygiene, and education. Rather than seeing murals as strange (aneh), youthful, or as commoditized signs of the global, visitors and residents of Yogyakarta have embraced murals positively, emphasizing their societal value and holding the art form apart from other equally public but unwanted visual matter such as illegible tags (Lee, A Troubled Vernacular: Legibility and Presence in Indonesian Activist Art, 2015, p. 10). Groups such as Apotik Komik approached the Yogyakarta authorities to counteract the "wild" scribbles of graffiti (corat-coretan) that they said defaced alleyways and lower-class neighborhoods. These artists were from fairly privileged backgrounds, and they had full monetary and legal support from the city's mayor (Barry, 2008). Now, upon entering Yogyakarta, one is greeted by murals stating, "Welcome to Jogja City! If you are polite we are too!" and "Don't make trouble in Jogja, Go home!!" Graffiti has turned into a "street art" with the full intent of the law behind it.

Do the messages street art conveys hold the same weight when they have been dictated by the government? Do they become an even more visceral experience of everyday propaganda when the words and images being depicted are not from the hearts and minds of the rakyat? Lee discusses the Indonesian vernacular for street art and the ways in which it has changed since the late 1990s. She says,

...seni jalanan does not smoothly translate into 'street art'. Artists reject the term seni jalanan, insisting that street art cannot be translated into Indonesian without diminishing its impact as a new and explicitly modern public domain, whereas cultural theorists, scholars, and observers attempt to make street art fit into a culturalist understanding of urban development and a vernacular lexicon of power and resistance. (Barry, 2008)

Jalanan (street, street-like, of the street) invokes the urban underclasses' survival strategies of panhandling and busking on the street, whereas street art as aesthetic practice maintains its integrity as an artistic endeavor tied to global influences and non-traditional materials and spaces. Street art today fulfills the mandate and occupies the position of public culture without having undergone the labor of witnessing, political voicing and reparation that graffiti and more activist art forms were tasked with in the early days of crisis after the fall of Suharto." (Lee, "Anybody Can Do It": Aesthetic 
Empowerment, Urban Citizenship, and the Naturalization of Indonesian Graffiti and Street Art, 2013)

Although many artists are grateful to have been given the opportunity to produce artwork in a public setting that they will not go to jail for creating, are the truly important social and political messages getting lost amongst the vast array of art being produced on the walls of the city? Upon first glance, it would seem so. Tourists pose in front of murals and graffiti strewn walls without having any context as to how or why they have been created. Residents of the city see copious amounts of colorful artwork on bridges and overpasses, on walls and doorways, naturalizing the view into a blur of paint. However, with the rise of the vigilant documentation by young artists uploading to social media platforms, the deeper socio-political messages are able to be highlighted, reflected, and preserved into the larger Indonesian cultural sphere.

\section{Preservation through Online Documentation}

This all-encompassing urge for the documentation of what was a predominantly temporary art form, and the realization that appreciation for such art has been growing both locally and worldwide, has resulted in a number of art galleries being established to cater to such needs. Alongside their wealthier, more established art-world contemporaries, groups of young street artists have created their own versions of street art galleries. Jakarta's Respecta Street Art Gallery (RSAG) has established an alternative way to disseminate the ideas associated with their medium, creating a living, continually evolving, and collectively curated website that posts and archives the street art of Indonesia.

The Indonesian Street Art Database (ISAD) was launched in January 2013 and is updated through the ISAD website, ISAD Facebook page, and ISAD Twitter feed. In an interview, ISAD Director Andi Rhararha described this process of amalgamation:

...we appealed to street artists and the general public to send in material over the past year. This has come through in the form of photographs, audio and video recordings from all over Indonesia. ... We also visit cities to promote ISAD through presentations. We want people to join us in documenting street art in Indonesia. On these trips, we spend time capturing art on the street as well. ... So far, we have about 2000 pieces of archival material. (Art Radar, 2012)

While this project may alter the context in which the work it gathers together is seen, its emphasis on urban social, political, and cultural issues is consistent with the movement's general thrust. Though no art is excluded from the sharing platform, the RSAG has most recently used the database to spread word of an event originally termed the Sunday Street Art Movement and now called Berbeda dan Merdeka 100\% (Diversity and Freedom 100\%). 


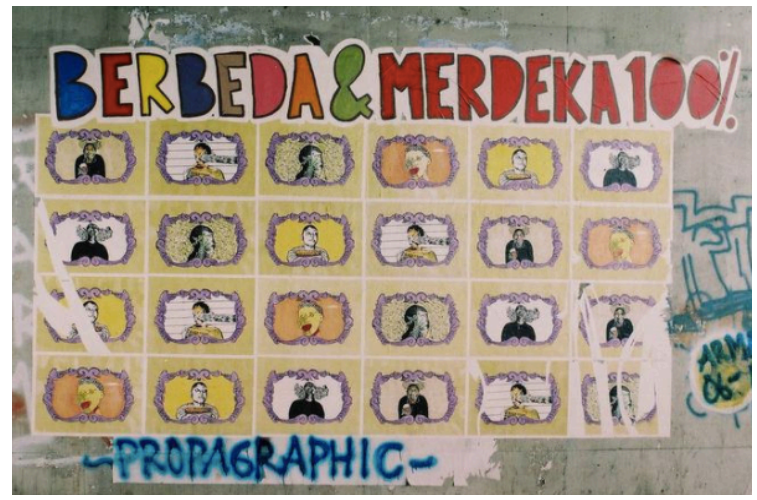

Figure 6. Berbeda \& Merdeka 100\% by unknown artist (Rizky, 2011). Licensed under Creative Commons on Flickr.com

On February 13, 2011, street artists throughout Indonesia used the Berbeda dan Merdeka 100\% website, Facebook, Twitter, and text messages to coordinate an event held simultaneously in 20 Indonesian cities and Singapore. It called out to the people of Indonesia to respect differences and practice tolerance. This plea to the country was in response to reports of interfaith violence in Indonesia, especially in the wake of the attack on members of the minority Ahmadiyah Islamic sect, and the burning of churches in Central Java. The event was wildly successful, and because of the ISAD it has lived on in perpetuity, helping to spur a wider audience to action.

Although Indonesia is currently in a relatively stable political period, and the oppressive thrust of the government is not weighing as heavily on citizens as during Suharto's regime, young Indonesian artist groups such as Taring Padi and the RSAG are still working collectively to make their voices heard. Today, Taring Padi is most concerned about the growing gap between rich and poor and the destruction of Indonesia's natural environment, while the RSAG focuses on documenting and reclaiming the budding commercialization of street art found throughout Indonesia. The role of the collective in each case has been used to educate the people of Indonesia, enabling the empowerment of the rakyat to band together to create an art of resistance in cases like the Lapindo mudflow disaster or Berbeda \& Merdeka 100\%. Using a medium that is easily and inexpensively created and distributed to the larger public, both Taring Padi and the RSAG have been able to use the greater acceptance for street art to further their messages of activism. Additionally, by accessing a potentially unlimited amount of exposure through online documentation, young artists are able to express themselves on a new level in a medium whose lifespan can so often be fleeting. By using such public spaces, both environmentally and digitally, Indonesians are able to truly connect with one another through art and develop a common goal for their community and their nation.

\section{Endnotes}

1 "Guided Democracy" was the term Suharto used to disguise his authoritarian rule, true democracy would not return to Indonesia for another 40 years (O'Rourke, 2002, p. 4). 
2 Indonesian for reformation.

3 Another term often used by such artists is "cultural worker", intended to reject the bourgeois class background often associated with artists (Taring Padi, n.d.).

${ }^{4}$ Claire Holt and Astri Wright have written extensively on these early revolutionary Indonesian artists -in the earliest art historical writing in English from this angle. In Holt's Art in Indonesia (1967) and Wright's Soul, Spirit, and Mountain (1994), both have provided a number of incredibly important insights into the lives and politics of artists such as Hendra Gunawan, whose artistic style grew out of the Indonesian Communist Party (NEKRA), which had been in favor in the earlier half of the $20^{\text {th }}$ century. Advocating for collectivism in a 1958 LEKRA publication, Hendra wrote: "From the people, by the people, and for the people" (Wright, 1994, p. 173).

5 These principles seem to fall directly in line with the hallmarks of the People's Global Action network. The PGA is a worldwide organization that has strongholds in many Asian countries, including Thailand, India, and Burma (Myanmar) (Peoples' Global Action, 2001).

${ }^{6}$ I use the term "low art" as a descriptor for art that is readily available to the masses and often easy to understand.

7 Astri Wright expounds on this idea of a collaborative art for community consciousness raising in her 1993 article "The Contemporary Artist as Activist". Here, Wright argues that in a society in which freedom of verbal expression is stifled, artwork becomes "intensely communicative texts that art in cultures with greater freedom lack" (p. 47). She references artist Moelyono, in particular, who undoubtedly inspired Taring Padi's transformation of theoretical aesthetics into social practice. His stated aims were to "develop the life of the people" and create awareness through artistic activity (p. 59).

8 In 2005, the first International Anti-Graffiti Conference was held in Berlin, Germany in an attempt to combat graffiti and impose stricter fines or punishments for offenders (DW Staff, 2005). In Indonesia, in a gubernatorial decree issued on April 18, the government decided to punish individuals or firms that write, draw, paste pamphlets or posters on walls in public places to with a maximum of 60 days in prison and a IDR20 million fine (Elyda, 2013).

9 Street art as a social and artistic movement has predominantly been documented by Western countries, ignoring a long tradition of graffiti in other areas of the world. Even in books such as Global Street Art: The Street Artists and Trends Taking Over the World (Boskin, 2014) and Street Art: The Graffiti Revolution (Cedar, 2008), which claim to be a "global" overview of the street art scene ignores Southeast Asian countries, lumping Asia, Africa, and Eastern Europe/Russia as "Non-Western art".

${ }^{10}$ For example, Shephard Fairey of Obey fame.

${ }^{11}$ Banksy has also been hypothesized to be a collective of people, due to the incredible speed with which "his" works seem to be put up. 
12 Mussolini used stencils to spread fascist propaganda throughout Italy (Martin, 2010).

13 The fine is $\$ 1000$ with the potentiality of a caning in Indonesia and $\$ 2000$ in Singapore. 


\section{References}

Arbuckle, H. (2006, May 12). Teeth of the rice plant (Taring Padi). Retrieved from http://www.undergrowth.org/teeth_of_the_rice_plant_taring_padi

Art Radar. (2012, August 15). Get Indonesian street art smart: Glimpses from ISAD. Retrieved from http://artradarjournal.com/2012/08/15/get-indonesian-streetart-smart-glimpses-from-isad/

Barry, S. (2008). Jalan seni jalanan (1 st ed.). Yogyakarta: Studium.

Beerkens, E. (n.d.). The student movement and the rise and fall of Suharto. Retrieved from http://www.universityworldnews.com/filemgmt_data/files/ The\%20rise\%20and\%20fall\%20of\%20Suharto.pdf

Bianpoen, C. (2009). Art and the nation: The cultural politics of Sukarno. In M. Knol, \& R. Z. Raben (Eds.), Beyond the Dutch: Indonesia, the Netherlands and the visual arts, from 1900 until now (pp. 94-103). Amsterdam: KIT Publishers.

Bishop, C. (2012). Participation and spectacle: Where are we now. In N. Thompson (Ed.), Living as form: Socially engaged art from 1991-2001 (pp. 34-45). New York: Creative Time Books.

Brighenti, A. (2010). At the wall: Graffiti writers, urban territoriality and the public domain. Space and Culture, 13(3), 315-322.

Bruhn, K. (2015, December 29). Art and social engagement in Yogyakarta, Indonesia: Ketjilbergerak and the legacy of Taring Padi. Retrieved from http:// www.seismopolite.com/art-and-social-engagement-in-yogyakarta-indonesiaketjilbergerak-and-the-legacy-of-taring-padi-i

Chanrochanakit, P. (2011, July). Deforming Thai politics as read through Thai contemporary art. Third Text, 25(4), 419-429.

Cooper, C. (2016, July). Collective improvisation. PORTAL Journal of Multidisciplinary International Studies, 13(2), 1-6.

Creagh, S. (2006, January 12). Cultural exchange makes a virtue of art with attitude. Sydney Morning Herald.

Cultural Policy and Cultural Democracy. (1990). In A. Goldbard, \& D. Adams (Eds.), Crossroads: Reflections on the politics of culture (pp. 107-109). Talmage, CA: DNA Press.

Currystrumpet. (Photographer). (2013, March 6). Brooklyn street art The Bushwick Collective Blek Le Rat [Photograph]. Retrieved from https://flic.kr/p/nwdmku

Dickens, L. (2008). Placing post-graffiti: The journey of the Peckham Rock. Cultural Geographies, 15(4), 471-480. 
DW Staff. (2005, April 7). Grappling with graffiti's darker side. (Deutsche Welle) Retrieved from http://www.dw.com/en/grappling-with-graffitis-darker-side/ a-1545450

Elyda, C. (2013, May 4). Ban on graffiti art questioned. Retrieved from http:// www.thejakartapost.com/news/2013/05/04/ban-graffiti-art-questioned.html

Ferrarese, M. (2014, April 3). Art is life. Retrieved from http://sea-globe.com/art-islife-malaysia-george-town-penang-graffiti-southeast-asia-globe/

Girardet, E. (Photographer). (2013, 1 December). Bicycle Mural. [Photograph]. Retrieved From https://flic.kr/p/i89f8d

Green Left Weekly. (2005, March 16). Semsar ciahaan (1952-2005). Retrieved from https:/www.greenleft.org.au/content/semsar-siahaan-1952-2005

Green, M. (2014). A beautiful mess: The evolution of political graffiti in the contemporary city. Retrieved from http://www.inquiriesjournal.com/a?id=1197

Ingham, S. (n.d.). Reformasi. Retrieved from http://inghaminindonesia.com/index.html

Lee, D. (2013, December 10). "Anybody can do it": Aesthetic empowerment, urban citizenship, and the naturalization of Indonesian graffiti and street art. City \& Society, 25(3), 304-327.

Lee, D. (2015, May). A troubled vernacular: Legibility and presence in Indonesian activist art. The Journal of Asian Studies, 74(2), 303-322.

MacPhee, J. (2007). Realizing the impossible: Art against authority. Chico, CA: AK Press.

Martin, J. (2010, December 16). Thinking about the origins of street art, part 1 . Retrieved from https:/hyperallergic.com/14166/origins-of-street-art/

Nyman, M. (2006). Democratising Indonesia: The challenges of civil society in the era of Reformasi. Copenhagen, Denmark: NIAS Press.

O'Rourke, K. (2002). Reformasi. Crows Nest, NSW, AUS: Allen \& Unwin.

Owens, Y. (2003). A very political art. Owens Y. A very political art. CMAJ: Canadian Medical Association Journal. 168(3), 320-321.

Democracy. (n.d.). In Oxford Living Dictionaries. Retrieved from https:// en.oxforddictionaries.com/definition/democracy

Peoples' Global Action. (2001). What is PGA?. Retrieved from https://www.nadir.org/ nadir/initiativ/agp/en/

Rizky, M. (2011). Berbeda \& Merdeka 100\%. Bandung, Indonesia. 
Rizky, M. (Photographer). (2011, May 13). Berbeda \& Merdeka 100\% [Online Image]. Retrieved from https://flic.kr/p/9kwuxh

Rubens, R. (Director). (2012). Reflecting in the Mud [Motion Picture]. Indonesia.

Rubens, R. (Director). (2012, August 9). Reflecting in the Mud [Film Still]. Retrieved from https://www.engagemedia.org/Members/ruben/videos/bercermin-dalamlumpur-en/view

Sanches, T., \& Silva, T. (2016). Grafitti, affective inscriptions and new expressions of visibilities in Sao Paulo's urban landscape. $R U A, 22(1), 5-18$.

Schacter, R. (2008). An ethnography of iconoclash: An investigation into the production, consumption and destruction of street-art in London. Journal of Material Culture, 13(1), 35-61.

Schwarz, A. (1997, July/August). Indonesia after Suharto. Retrieved from https:// www.foreignaffairs.com/articles/asia/1997-07-01/indonesia-after-suharto

Seah, J. (2014). Street spray love: Tracing the evolution of Singapore's growing street art Scene. Retrieved from http://a-list.sg/street-spray-love/

Sinaga, D. (2011). Not for the sake of a fine arts discourse. In A. Sloman, J. E. Trap, \& Reuben (Eds.), Seni Membongkar Tirani, 23-36.

Song, S.-W. (2008). Back to basics in Indonesia? Reassessing the Pancasila and Pancasila state and society, 1945-2007. Ann Arbour, MI: ProQuest Information and Learning Co.

Taring Padi. (2012, February 15). Buku Taring Padi "seni membongkar tirani". Retrieved from http://www.taringpadi.com/buku-taring-padi-senimembongkar-tirani/

Taring Padi (Art Collective). (2012, February 15). Taring Padi: Seni Membongkar Tirani (Art Smashing Tyranny) [Online Image]. Retrieved from http:// www.taringpadi.com/buku-taring-padi-seni-membongkar-tirani/

Taring Padi. (n.d.). About. Retrieved from http://www.taringpadi.com/

Unknown. (1946). Occupation Tangerang 28 May 1946. On the concrete wall of a bunker, the TNI carries out starvation. Dienst voor Legercontacten. National Archives of the Netherlands.

Unknown. (Photographer). (1946). Mural in Tangerang on Concrete Bunker Wall. [Online Image]. Retrieved From The National Archives Of The Netherlands Database.

White, E. (2012, October 5). Reflection in the mud: A lunch-time presentation. Retrieved from http://northquad.umich.edu/reflection-in-the-mud/ 
Wright, A. (1993). The contemporary Indonesian artist as activist. (L. Means, Ed.), Cultural environments in contemporary Southeast Asia, 47-66.

Wright, A. (1994). Soul, spirit and mountain: Preoccupations of contemporary Indonesian painters. New York: Oxford University Press.

Wright, A. (n.d.). Thoughts from the crest of a breaking wave. In A. Kuss, D. Moon, M. Jaarsma, M. Hirota, \& N. Wasmuth (Eds.), AWAS! Recent art from Indonesia (pp. 49-69). Yogyakarta: Cemeti Art Foundation. 